\title{
Ortaokul Öğrencilerinin Okuma Motivasyonları ile Türkçe Dersi Akademik Başarıları Arasındaki İlişkinin İncelenmesi ${ }^{1}$
}

\author{
Fuat ATAŞ² $\quad$ Erhan AKIN ${ }^{3}$
}

\author{
Gönderim Tarihi: 16.09 .2021
}

Kabul Tarihi: 15.10 .2021

Yayın Tarihi: 19.10 .2021

Öz: Bu araştırma ortaokul öğrencilerin okuma motivasyonu ile Türkçe dersi akademik başarıları arasındaki ilişkiyi tespit etmek amacıyla yapılmıştır. Bu amaçla Bingöl iline bağlı Sultan Abdulhamid Han Ortaokulu öğrencilerinin Türkçe dersi akademik başarıları ile okuma motivasyonları arasındaki ilişki incelenmiştir. Nicel yöntemlerden biri olan tarama yöntemi ile yürütülen bu araştırma Sultan Abdulhamid Han Ortaokulunun 5, 6, 7 ve 8. sınıflarının A/B/C şubelerinde eğitim gören 395 öğrenciden elde edilen verilere dayanmaktadır. Verilerin toplanmasında Wigfield ve Guthrie (1997) tarafından geliştirilen ve Durmuş (2014) tarafınca Türkçeye uyarlanan “Okuma Motivasyonu Ölçeği” kullanılmıştır. Bu ölçekten alınan puanlar öğrencilerin 2018-2019 yılı sonunda elde ettikleri Türkçe dersi ortalamaları ile karşılaştırılmıştır. Araştırma alt problemleri kapsamında öğrencilerin okuma motivasyonları ile Türkçe dersi akademik başarıları arasında; cinsiyete, sınıf düzeyine, anne ve baba eğitim düzeyine, evinde kütüphane bulundurma durumuna ve okul öncesi eğitim alma durumuna göre bir farklılaşma olup olmadığı araştırılmıştır. Araştırma bulguları incelendiğinde öğrencilerin cinsiyete, anne ve baba eğitim düzeyine göre anlamlı bir farklılaşma tespit edilmemiş; sınıf düzeyine, evinde kütüphane bulundurma durumuna ve okul öncesi eğitim alma durumuna göre anlamlı bir farklılaşma tespit edilmiştir. Araştırma sonuçlarından hareketle araştırmaya ve araştırmacılara yönelik önerilerde bulunulmuştur.

Anahtar Kelimeler: Okuma, Motivasyon, Akademik Başarı

\section{Investigation of the Relationship Between the Reading Motıvations of Secondary School Students and Their Academic Academic Achievements of Turkish Course}

\begin{abstract}
This study was conducted to determine the relationship between students' reading motivation and Turkish course academic achievement. For this purpose, the relationship between Turkish course academic achievement and reading motivation of Sultan Abdulhamid Han Secondary School students in Bingöl province was examined. This research is based on the data obtained from 395 students studying at 5th, 6th, 7th and 8th A / B / C branches of Abdulhamid Han Secondary School. While obtaining data from students, the results of the analysis obtained from the four-choice Likerttype reading motivation scale, which was adapted to Turkish, consisting of 29 items, were compared with the Turkish course averages that students obtained at the end of 2018-2019. Within the scope of the research sub-problems, among the students' reading motivation and Turkish course academic success; It was investigated whether there is a differentiation according to gender, class level, parents' education level, having a library at home and having pre-school education. When the research findings were examined, no significant differentiation was found according to the gender of the students and the education level of the parents; A meaningful differentiation was determined according to class level, having a library at home and having pre-school education. As a result of the research, it was determined that there was no significant difference between the students' reading motivation and their Turkish course academic achievement. Based on the research results, suggestions were made for the research and researchers.
\end{abstract}

Keywords: Reading, Motivation, Academic Success

\section{GíRIŞ}

İnsanoğlu varoluşundan bu yana sürekli iletişim halinde olmuştur. İletişimin kaynağı olan dil ile bunu sürdürmüştür. Bu bakımdan dil üzerine yapılan çalışma ve araştırmaların sayısı bir hayli fazladır. Buna rağmen dil için yapılan bu çalışmaların yeterli olmadığı düşünülmektedir. Çünkü dil,

\footnotetext{
${ }^{1}$ Bu çalışma, birinci yazarın ikinci yazar danışmanlığında hazırlamış olduğu “Ortaokul Öğrencilerinin Okuma Motivasyonları İle Türkçe Dersi Akademik Başarıları Arasındaki İlişkinin İncelenmesi" adlı yüksek lisans tezinden üretilmiştir.

2 MEB, Türkiye, fuatatas_12@hotmail.com, ORCID: 0000-0003-1064-9287

${ }^{3}$ Siirt Üniversitesi, Türkiye, erhanakin49@hotmail.com, ORCID: 0000-0003-2372-9331
} 
sürekli değişen ve gelişim gösteren bir varlıktır. Dilin bu özelliği de dil ile ilgili yapılan çalışmaların alana yeterli gelmediğini göstermektedir.

Dil, tarihten bugüne kadar birçok araştırmacı tarafından tanımlanmıştır. Bu tanımlamalarda da dil, farklı farklı yönleriyle ve özellikleriyle aktarılmıştır. Genel anlamda dil ile ilgili yapılan çalışmalara bakıldığında dilin çok yönlülüğüne her zaman dikkat çekilmiştir. Yapılan bazı tanımlara bakıldığında şu hususların dikkate sunulduğu görülmüştür:

Geniş anlamda dil, kimi ses veya ses gruplarının somut ya da soyut varlığın hayalini zihinde uyandırması sürecinden ibarettir. İşlevi bakımından ele alındığında ise dil, bir araçtan başka bir şey değildir. Manevi bakımdan ise hayatın aldığı bir şekildir ve milletlerin çağlar boyunca yaşadığ1 tarihinin adeta özetidir (Kaplan, 2001: 163). Hem araç hem de amaç olarak görülen dil, ulusların yaşamsal faaliyetlerinin bir yansımasıdır.Dilin toplumsal hayattaki rolü bir gerçekliktir. Dil, sadece bir iletişim aracı değildir. İnsanların hayatlarında her dönemde varlığııı sürdüren bir olgudur.Dil, diğer insanlarla ilişkilerimizde bize aracılık eden ve hayatımızın bütün aşamalarında yer alan bir kavramdır. Çarşıda, pazarda, evde, okulda, cadde ve sokakta kısacası her yerde dil bizimledir. Dilin bu geniş işlevselliği önemini daha da arttırmaktadır. Dil becerisi gelişmiş insanların okumaya istekli kişiler oldukları görülmektedir. Okuyan, anlayan, okuma becerisi gelişmiş kişilerin dili daha iyi kullandıkları görülmektedir. Okuma bir faaliyettir. Okuyan insanların yorum yapabilme gücü, muhakeme biçimleri ve analiz edebilme yönleri her zaman üst seviyededir. Okuma gerek zihinsel ve gerekse de fiziksel unsurların beraber kullanıldığı karmaşık yapıda olan bir dil becerisidir (Özbay, 2009: 2).

Dil hem bir iletişim faaliyeti hem de bilgiyi doğru şekilde aktarma faaliyeti olarak değerlendirilmektedir. Yani dil düşünce sahasında da kendisini göstermektedir. Okuma faaliyeti de aslında bir yönüyle iletişim faaliyetidir. Çünkü şairler ve yazarlar anlatmak istediklerini okuyucuya aktarırken okuma becerisi ile bunu yapmaktadır. Bu yönüyle de bakıldığında okumanın da iletişim ile iç içe olduğunu görülmektedir. Dil iletişimin sağlandığı ve bilginin aktarıldığı en önemli araçlardan biridir (Yalçın, 2002: 9).İnsanlar konuştuğu dili doğdukları andan itibaren hazır bulur ancak dil becerisinin gelişimi okuma ve okuduğunu anlama becerisine de bağlıdır.Çongur (1995: 54)'a göre ise okuma, "Her dilin alfabesinde yer alan harflerle yazma ve konuşmaya sekil ve yön veren işaretlerin, zihinde görme ve işitme organlarıyla ortaklaşa yürüttüğü bir faaliyettir."

Okuma faaliyetinin ortaya çıkması aslında ses, şekil ve bazı simgelere bağlı olduğundan bu durumun da yazı ve dil ile ilişkisini ortaya koyması bakımından önemini göstermektedir. Yani dil becerilerinden biri olan okumanın yazı bulunduktan sonra ortaya çıktığı görülmektedir. Demirel' e (2003: 77) göre okuma, bireyin bilişsel davranışları ile psikomotor becerilerini ortak bir şekilde çalıştırarak yazılı sembollerden anlam çıkarmasıdır.Dilin çok yönlülüğüne bakıldığında temel dil becerilerinden olan okuma becerisi üzerine çalışmaların yapılması önem arz etmektedir. Çünkü anlama becerisi olarak okumanın önemli bilgi kaynaklarından biri olduğu görülmektedir. Özellikle teknolojinin gelişmesiyle her alanda olduğu okuma becerisi de bundan etkilenmiştir. Artık tek bir yöntem veya tek bir materyal kullanımı yerine birden fazla seçenek aynı anda değerlendirilmektir (Sarıkaya, 2017). Bu da ayrı bir motivasyon gerektirmekte ve öğrenciler için özel teknikler geliştirmenin gerekliliğini ortaya koymaktadır. Çünkü çağımızda bilgi ve iletişim teknolojileri artık takip edilemeyecek bir şekilde gelişmektedir. Özellikle internet kullanımının yaygınlaşması birçok şeyin değişmesine neden olmuştur (Sarıkaya, 2018). Bu durum okuma motivasyonu ile ilgili çalışmaların yapılması ihtiyacını doğurmakta ve bu çalışmanın çıkış noktasını oluşturmaktadır. 


\section{Araştırmanın Önemi ve Amacı}

Bu çalışmada öğrencilerin Türkçe dersindeki akademik başarılarını etkilediği düşünülen okuma, okuma becerisi ve okuma motivasyonu gibi kavramlar üzerinde durulmuştur. Ortaokul öğrencilerinin okuma motivasyonları ile Türkçe dersi akademik başarıları arasındaki ilişkiyi ortaya koyacak bu çalışma ileride yapılacak çalışmalar için yol göstermesi ve benzer çalışmalar için strateji belirlemesi bakımından öneme sahiptir.

$\mathrm{Bu}$ araştırmada ortaokul öğrencilerinin okuma becerileri alışkanlığının hem akademik hem de hayat başarılarına etki ettiği düşüncesinden hareketle ortaokul öğrencilerinin okuma motivasyonları ile Türkçe dersi akademik başarıları arasındaki ilişki üzerinde durulmuştur. Bu amaç doğrultusunda ortaokul öğrencilerinin okuma motivasyonu ile Türkçe dersi akademik başarıları arasındaki ilişkiyi ortaya koymak amaçlanmıştır. Bu amaca bağlı olarak şu alt problemlere yanıt aranmıştır:

1. Ortaokul öğrencilerinin okuma motivasyonu ile Türkçe dersi akademik başarıları arasındaki ilişki cinsiyete göre değişkenlik göstermekte midir?

2. Ortaokul öğrencilerinin okuma motivasyonu ile Türkçe dersi akademik başarıları arasındaki ilişki sınıf düzeyine göre değişkenlik göstermekte midir?

3. Ortaokul öğrencilerinin okuma motivasyonu ile Türkçe dersi akademik başarıları arasındaki ilişki anne eğitim düzeyine göre değişkenlik göstermekte midir?

4. Ortaokul öğrencilerinin okuma motivasyonu ile Türkçe dersi akademik başarıları arasındaki ilişki baba eğitim düzeyine göre değişkenlik göstermekte midir?

5. Ortaokul öğrencilerinin okuma motivasyonu ile Türkçe dersi akademik başarıları arasındaki ilişki öğrencilerin evinde kütüphane bulunma durumuna göre değişkenlik göstermekte midir?

6. Ortaokul öğrencilerinin okuma motivasyonu ile Türkçe dersi akademik başarıları arasındaki ilişki öğrencilerin okul öncesi eğitim alma durumuna göre değişkenlik göstermekte midir?

\section{YÖNTEM}

\section{Araştırmanın Modeli}

Ortaokul öğrencilerinin okuma motivasyonları ile Türkçe dersleri arasındaki akademik ilişkinin incelenmesini amaçlayan bu çalışmada nicel araştırma yöntemi kullanılmıştır. Nicel araştırmalar, var olan gerçekliğin araştırmacılardan bağımsız olduğunu ileri süren, kendi dışında kalan gerçekliğin analiz edilebileceğini savunan sistematik, nesnel ve pozitivist bir anlayış içermektedir (Büyüköztürk, Çakmak, Akgün, Karadeniz ve Demirel, 2017). Nicel araştırmalar; nicel verilerin toplanmasını ve analiz edilmesini gerektirmekle birlikte, toplanan nicel verilerle gözlemlenen değişkenler arasındaki ilişkilere dair problemlere cevap aramaktadır (Altunışık, Coşkun, Bayraktaroğlu ve Yıldırım, 2010).

$\mathrm{Bu}$ araştırma nicel analiz yöntemlerinden tarama modeli ile desenlenmiştir. Tarama modeli araştırmaları katılımcıların bir konu, olgu veya olaya dair ilgi, görüş, tutum, beceri ve yetenek gibi özelliklerini belirlemek için kullanılır. Ağırlıklı olarak büyük örneklem grupları için tercih edilen bu modelde temel amaç var olan mevcut bir durumu gerçekçi bir perspektifle yansitmaktır. Araştırmacı bu modelde mevcut durumu değiştirmeden olduğu gibi ele almalıdır (Büyüköztürk, Çakmak, Akgün, Karadeniz ve Demirel, 2017). 


\section{Çalışma Evreni}

Araştırmanın çalışma evrenini 2018-2019 eğitim öğretim yılında Bingöl ili Merkez ilçesinde eğitim veren Sultan Abdulhamid Han Ortaokulu 5. 6. 7. ve 8. sınıf öğrencileri oluşturmaktadır. Örneklemi ise araştırma verilerini toplamak amacıyla uygulanan veri toplama aracını yanıtlamayı kabul eden 5, 6, 7 ile 8. sınıfların A/B/C şubelerinde eğitime devam eden 395 ortaokul öğrencisi oluşturmaktadır.

\section{Veri Toplama Araçları}

Araştırmada Wigfield ve Guthrie (1997) tarafından geliştirilen ve Durmuş (2014) tarafınca Türkçeye uyarlanan "Okuma Motivasyonu Ölçeği” kullanılmıştır. 29 maddeden oluşan "Okuma Motivasyonu Ölçeği"ndeki maddelerin güvenilirliğini hesaplamak için kullanılan iç tutarlılık katsayısı olan "Cronbach Alpha” 0.904 olarak çok yüksek bulunmuştur (Durmuş,2014). Bunun yanı sıra araştırmacılar tarafınca geliştirilen “Kişisel Bilgi Formu” kullanılmıştır

\section{Verilerin Analizi}

Sultan Abdulhamid Han Ortaokulu öğrencilerinin Okuma Motivasyonu Ölçeğine verdikleri yanıtların puanları SPSS 21.0 paket programı ile analiz edilmiştir. Ölçekteki maddeler uygulandıktan sonra öğrencilerinin motivasyonlarına ilişkin görüşleri ile toplam ve ortalama puanları hesaplanmıştır. Okuma motivasyonu ölçeği için normallik testine bakılmış ve puanların normal dağılım gösterdiği görülmüştür. Bu nedenle araştırmaya katılan ortaokul öğrencilerinin okuma motivasyonuna ilişkin görüşleri t-testi ve ANOVA analizi yapılarak varyans analizi ile incelenmiştir.

Tablo 1. Güvenirlik Analizi Sonucu Elde Edilen Cronbach Alpha Değeri

\begin{tabular}{lc}
\hline Cronbach's Alpha & $N$ \\
\hline 0,887 & 29 \\
\hline
\end{tabular}

Tablo 1 incelendiğinde cronbach alpha değerinin 0,887 çıtığı görülmektedir. Bu da Cronbach's Alpha değerinin 0,80-1,00 aralığında bulunduğunu ve bu anket verilerinin çok güvenilir olduğunu göstermektedir.

\section{BULGULAR}

$\mathrm{Bu}$ araştırmanın amacı, Sultan Abdulhamid Han Ortaokul öğrencilerinin aldığı notların, cinsiyet, anne-baba eğitim düzeyinin, evde kütüphane olup olmama durumunun ve okul öncesi eğitim alıp almama durumuna ilişkin görüşlerinden hareketle Okuma Motivasyonu Ölçeği kullanılarak bu durumun akademik başarılarına etkisini tespit etmektir. Bu amaçla, araştırma sonucunda elde edilen bulgular aşağıda açıklanmıştır:

\section{Öğrencilerin Cinsiyet Dağılımına İlişkin Bulgular}

Grafik 1.'de yer alan verilere katılımda bulunan öğrencilerin \%45'i kız ( $f=178), \% 55$ ' i $(f=217)$ ise erkek öğrencilerden oluşmaktadır. Çalışma grubundaki kız öğrenciler ile erkek öğrenciler arasında birbirine yakın bir denge oluştuğu görülmektedir. Öğrencilerin cinsiyet dağılımı Grafik 1.'de sunulmuştur. 


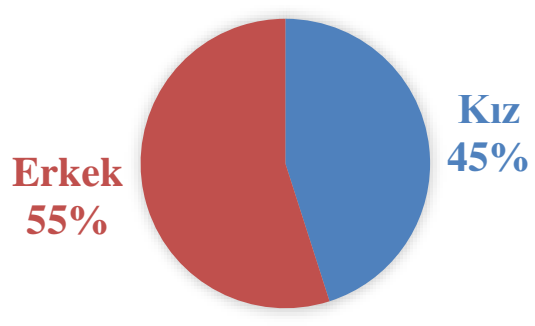

Grafik 1. Öğrencilerin Cinsiyet Dağılımı

Araştırmaya katılan Sultan Abdulhamid Han Ortaokulu öğrencilerinin okuma motivasyonu ölçeğine ilişkin ortalama puanları ve t-testi analizi sonuçları Tablo 2'de sunulmuştur.

Tablo 2. Öğrencilerin Cinsiyete Göre Ortalamaları ve T-Testi Sonuçları

\begin{tabular}{|c|c|c|c|c|c|c|}
\hline \multirow[b]{2}{*}{$f$} & $\underline{\text { Varyans Eșitliği Testi }}$ & \multicolumn{2}{|c|}{$\underline{T-T e s t i ~ O r t a l a m a l a r i}$} & \multirow[b]{2}{*}{ Sig. (2) } & \multirow[b]{2}{*}{$X^{-}$} & \multirow[b]{2}{*}{ SD } \\
\hline & $\begin{array}{l}\text { Sig. } \\
\text { (1) }\end{array}$ & $\mathbf{T}$ & $\mathrm{df}$ & & & \\
\hline \multirow{2}{*}{0,606} & \multirow{2}{*}{0,438} & $-1,315$ & 106 & 0,191 & $-0,19103$ & 0,14525 \\
\hline & & $-1,538$ & 13,599 & 0,147 & $-0,19103$ & 0,12419 \\
\hline
\end{tabular}

Öğrencilerin okuma motivasyonu ölçeğine ilişkin ortalama puanları ve t-testi analizi sonuçlarına ilişkin olarak Tablo 2. incelendiğinde, sigma 1 değerinin 0,438 olması sonucunda varyansların homojen olduğu yani eşit olduğu görülmektedir. Sigma 2 değerinin 0,191 olması 0,05'ten büyük olduğunu ve cinsiyete ilişkin anlamlı bir farklılık olmadığını göstermektedir.

\section{Öğrencilerin Sınıf Düzeyinin Okuma Motivasyonu Ölçeğine Etkisine İlişkin Bulgular}

Grafik 2.'de yer alan verilere katılımda bulunan öğrencilerin \%28'i 5. sınıf ( $f=110), \% 27$ 'si 6 . sinıf $(f=105), \% 27$ 'si 7. sınıf $(f=108), \% 18^{\prime} i$ ise 8 . sınıf $(f=72)$ öğrencilerinden oluşmaktadır. Elde edilen verilerden hareketle çalışma grubundaki öğrencilerin büyük çoğunluğunun 5. sinıf öğrencilerinden oluştuğu görülmektedir. Öğrencilerin sınıf düzeylerine ilişkin dağılımları Grafik 2.'de sunulmuştur.

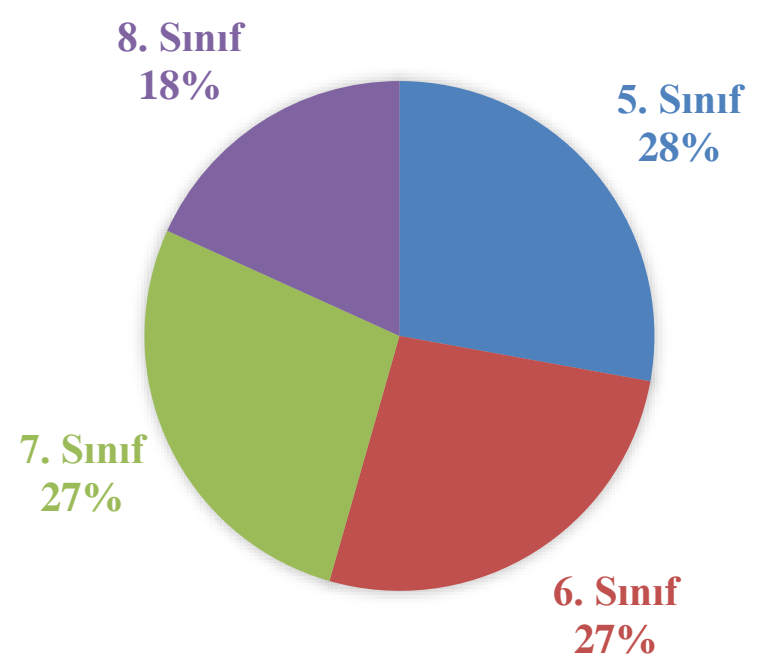

Grafik 2. Öğrencilerin Sınıf Mevcudu Dağılımları 
Tablo 3. Öğrencilerin Sınıf Düzeyinin Okuma Motivasyonu Ölçeğine Etkisi ve Anova Analizi

\begin{tabular}{|c|c|c|c|c|c|}
\hline & Kareler Toplamı & $d f$ & Ort. & $f$ & $p$ \\
\hline Gruplar Arası & 10,040 & 3 & 3,347 & \multirow{3}{*}{15,540} & \multirow{3}{*}{0,000} \\
\hline Grup İçi & 84,203 & 391 & 0,215 & & \\
\hline Toplam & 94,243 & 394 & & & \\
\hline \multirow[t]{2}{*}{$\begin{array}{l}\text { Sınıf } \\
\text { Düzeyi }\end{array}$} & $\begin{array}{l}\text { Sinıf } \\
\text { Karşılaştırması }\end{array}$ & Ort. & $S D$ & $p$ & \\
\hline & $6 . \operatorname{sinif}$ & 0,16071 & 0,06331 & 0,056 & \\
\hline \multirow[t]{3}{*}{ 5.sinif } & 7.sinif & $0,35873^{*}$ & 0,06286 & 0,000 & \\
\hline & 8.sinif & $0,39816^{*}$ & 0,07035 & 0,000 & \\
\hline & 5.sinif & $-0,16071$ & 0,06331 & 0,056 & \\
\hline \multirow[t]{3}{*}{$6 . \sin 1 f$} & 7.sinif & $0,19802^{*}$ & 0,06360 & 0,011 & \\
\hline & 8.sinif & $0,23745^{*}$ & 0,07101 & 0,005 & \\
\hline & 5. sinif & $-0,35873^{*}$ & 0,06286 & 0,000 & \\
\hline \multirow[t]{3}{*}{ 7.sinif } & $6 . \operatorname{sinif}$ & $-0,19802^{*}$ & 0,06360 & 0,011 & \\
\hline & $8 . \operatorname{sinif}$ & 0,03943 & 0,07060 & 0,944 & \\
\hline & 5.sinif & $-0,39816^{*}$ & 0,07035 & 0,000 & \\
\hline \multirow[t]{2}{*}{ 8.sinif } & $6 . \operatorname{sinif}$ & $-0,23745^{*}$ & 0,07101 & 0,005 & \\
\hline & 7.sinif & $-0,03943$ & 0,07060 & 0,944 & \\
\hline
\end{tabular}

Araştırmaya katılan ortaokul öğrencilerinin sınıf düzeylerinin Anova analizi sonucuna bakıldığında sigma değerinin 0,00 çıktığ ve 0,05 ten küçük olduğu anlamlı bir farklılık olduğunu göstermektedir. Anlamlı farklılığın hangi sınıf düzeylerinde olduğunu anlamak için yapılan Anova analizi sonucunda çıkan post hoc analizi sonucunda farklılığın hangi sınıf düzeylerinde olduğu anlaşılmaktadır. Tukey testi sonucunda gruplar arası farklılığın hangi gruplarda olduğu sigma değerlerine bakıldığında anlaşılmaktadır. Sigma değerlerinin 0,05 ten küçük olduğu yerler anlamlı farklılı̆̆ın olduğu yerleri göstermektedir.

\section{Öğrencilerin Anne Eğitim Durumlarına İlişkin Bulgular}

Tablo 4. Öğrencilerin Anne Eğitim Düzeyinin Akademik Başarılarına Etkisinin Anova Analizi Sonuçları

\begin{tabular}{llllll}
\hline & Kareler Toplamı & $d f$ & Ort. & $f$ & $p$ \\
\hline Gruplar Arası & 2,253 & 4 & 0,563 & 2,388 & 0,051 \\
Grup İçi & 91,990 & 390 & 0,236 & & \\
Toplam & 94,243 & 394 & & & \\
\hline
\end{tabular}

Araştırmaya katılan ortaokul öğrencilerinin annelerinin aldıkları eğitim düzeyinin akademik başarılarına etkisini belirlemek için anova analizi yapılmıştır. Tablo 4'ün analiz sonucuna bakıldığında sigma değerinin 0,051 çıtı $\breve{g} 1$ ve alpha değerinin 0,05 'ten büyük olduğu görülmektedir. 
Sigma değerleri sonucunda anne eğitim düzeyinin akademik durumlara etkisinde anlamlı bir farklılık olmadığını göstermektedir.

\section{Öğrencilerin Baba Eğitim Durumlarına İlişkin Bulgular}

Tablo 5. Öğrencilerin Baba Eğitim Düzeyinin Akademik Başarılarına Etkisinin Anova Analizi Sonuçları

\begin{tabular}{llllll}
\hline & Kareler Toplamı & $d f$ & Ort. & $f$ & $p$ \\
\hline Gruplar Arası & 0,073 & 4 & 0,018 & 0,075 & 0,990 \\
Gruplar İçi & 94,170 & 390 & 0,241 & & \\
Toplam & 94,243 & 394 & & & \\
\hline
\end{tabular}

Araştırmaya katılan ortaokul öğrencilerinin babalarının aldıkları eğitim düzeyinin akademik başarılarına etkisini belirlemek için anova analizi yapılmıştır. Tablo analizi sonucuna bakıldığında sigma değerinin 0,990 çıtı̆̆ ve alpha 0,05 ten büyük olduğu görülmektedir. Sigma değerleri sonucunda baba eğitim düzeyinin akademik durumlara etkisinde anlamlı bir farklılık olmadığını göstermektedir.

\section{Öğrencilerin Evde Kütüphane Olması Durumlarına İliş̧in Bulgular}

Tablo 6. Öğrencilerinin Evde Kütüphane Olma ve Olmama Durumuna Göre T-Testi Analizi Sonuçları

\begin{tabular}{lllllll}
\hline$f$ & $\begin{array}{l}\text { Sig. } \\
(\mathbf{1})\end{array}$ & $\boldsymbol{t}$ & $d f$ & $\begin{array}{l}\text { Sig. } \\
\text { (2) }\end{array}$ & Ort. & SD \\
\hline \multirow{2}{*}{081} & 0,299 & 3,050 & 393 & 0,002 & 0,16005 & 0,05247 \\
& & 3,099 & 248,044 & 0,002 & 0,16005 & 0,05165 \\
\hline
\end{tabular}

Araştırmaya katılan öğrencilerin evde kütüphane bulundurma durumuna göre t-tesi analizi sonucuna bakıldığında sigma değerinin 0,02 çıtı̆̆ ve alpha değerinin 0,05'ten küçük çıtı̆̆ görülmektedir. Bu durum evde kütüphane bulundurma durumunun öğrencilerin akademik başarıları açısından anlamlı bir farklılık oluşturduğunu göstermektedir.

\section{Öğrencilerin Okul Öncesi Eğitimi Alma Durumlarına İlişkin Bulgular}

Tablo 7. Öğrencilerin Okul Öncesi Eğitim Alma Durumlarına GöreT-Testi Analizi Sonuçları

\begin{tabular}{lllllll}
\hline$f$ & $\begin{array}{l}\text { Sig. } \\
\text { (1) }\end{array}$ & $t$ & $d f$ & $\begin{array}{l}\text { Sig. } \\
\text { (2) }\end{array}$ & Ort. & SD \\
\hline 0,511 & 0,475 & 2,406 & 393 & 0,017 & 0,13445 & 0,05589 \\
& 2,284 & 161,266 & 0,024 & 0,13445 & 0,05887 \\
\hline
\end{tabular}

Tablo 7 İncelendiğinde Sultan Abdulhamid Han Ortaokulu öğrencilerinin okul öncesi eğitim alma durumlarına göre t-testi analizi sonucuna bakıldığında sigma değerinin 0,017 çıtı̆̆ 1 ve $0,05^{\prime}$ ten küçük olduğu görülmektedir. Bu durumda öğrencilerin okul öncesi eğitim alma durumlarının akademik başarılarına etki ettiği anlamlı bir şekilde görülmektedir. Okul öncesi eğitim alan adayların ortalama puanlarının belirgin bir şekilde almayanlara göre yüksek olduğu eğitim alan öğrencilerin ortalama puanlarının 3,05 olduğu almayanların ortalama puanlarının 2,91 olduğu görülmektedir. 
Tablo 8. Öğrencilerin Okul Öncesi Eğitim Alma Durumlarına Göre Ortalamaları

\begin{tabular}{lllll}
\hline $\begin{array}{l}\text { Okul Öncesi Ĕ̈itim Aldınız } \\
\text { Mi? }\end{array}$ & $N$ & Ort. & SD & SD Ort. \\
\hline Evet & 293 & 3,0533 & 0,47179 & 0,02756 \\
Hayır & 102 & 2,9189 & 0,52540 & 0,05202 \\
\hline
\end{tabular}

Tablo 8 İncelendiğinde Sultan Abdulhamid Han Ortaokulu öğrencilerinin okul öncesi eğitim alma durumlarına göre ortalamalarının analizi sonucuna bakıldığında 293 öğrencinin okul öncesi eğitim aldığ1, 102 öğrencinin ise okul öncesi eğitim almadı̆̆ı tespit edilmiştir. Öğrenci ortalamaları incelendiğinde okul öncesi eğitim alan öğrencilerin okuma motivasyonları ölçeğinden elde ettikleri ortalamaların daha yüksek olduğu sonucuna varılmıştır.

\section{Öğrencilerin Akademik Başarılarının, Okuma Motivasyonu Ölçeğinden Alınan Puanlarına İlişkin Bulgular}

Tablo 9. Öğrencilerin Akademik Başarılarının, Okuma Motivasyonu Ölçeğinden Alınan Puanlarına İlişkin Anova Analizi

\begin{tabular}{llllll}
\hline & Kareler Toplami & $d f$ & Ort. & $f$ & $p$ \\
\hline Gruplar Arası & 0,463 & 4 & 0,116 & 0,481 & 0,749 \\
Grup İçi & 93,780 & 390 & 0,240 & & \\
Toplam & 94,243 & 394 & & & \\
\hline
\end{tabular}

Yapılan Anova analizi sonucunda Sultan Abdulhamid Han Ortaokulu öğrencilerinin ölçekten aldıkları puanların akademik başarılarına göre durumu incelendiğinde sigma değerinin 0,749 olduğu görülmekte ve 0,05 alpha değerinden büyük olduğu anlaşılmaktadır. Bu analiz sonucunda akademik başarının okuma motivasyonu ölçeğinden alınan puanlarla anlamlı bir farklılık olmadığını göstermektedir.

\section{TARTIŞMA, SONUÇ ve ÖNERILLER}

\section{Tartışma}

Ortaokul öğrencilerinin okuma motivasyonları ile Türkçe dersi akademik başarıları arasındaki ilişkinin incelendiği bu çalışmadan elde edilen nicel sonuçlar alan yazın kapsamında yapılan diğer araştırma sonuçları ile karşılaştırılmıştır. Bu bağlamda literatür taraması yapılmış, ilgili araştırmalar tartışma kapsamına dâhil edilmiştir.

Araştırmanın Okuma Motivasyonu Ölçeği ile alt problemlerinde yer alan ve birinci alt problem olan ortaokul öğrencilerinin okuma motivasyonları ile Türkçe dersi akademik başarıları arasındaki ilişkinin cinsiyete göre anlamlı bir değişkenlik göstermediği sonucuna ulaşılmıştır. Alan yazın incelendiğinde cinsiyet değişkeninin anlamlı farklılıklar ortaya koymadığını gösteren çalışmalar vardır. Soysal (2014), çalışmasında öğrencilerin okuduğunu anlama düzeylerini farklı değişkenler açısından incelediğinde cinsiyet değişkeninin okuma anlama düzeyinde anlamlı bir farklılığa sebep olmadığını tespit ederek çalışmamıza benzer sonuç elde etmiştir.

Çetinkaya (2004) da yapmış olduğu “Afyon Merkezindeki İlköğretim 8. Sınıf Öğrencilerinin Okuma Alışkanlığgı" adlı çalışmasında son bir yılda okunan kitap sayısında cinsiyet faktörünün önemli oranda etkili olmadığı sonucuna ulaşmıştır. Çalışma, bu yönüyle yaptığımız çalışma ile benzer 
sonuçlar ortaya koymaktadır.

Alan yazın incelendiğinde cinsiyet faktörünün anlamlı farklılıklar ortaya koyduğunu gösteren çalışmalar da vardır. Topçu (2005), “İlköğretim 6, 7 ve 8. Sınıf Öğrencilerinin Okuma Alışkanlıkları (Kayseri Örneği)" çalışmasında, cinsiyet faktörünün okuma alışkanlığı üzerinde anlamlı farklılık oluşturduğunu belirterek çalışma sonucumuzdan farklı bir sonuca ulaşmıştır.

Keleş (2006), çalışmasında kız öğrencilerin lehine anlamlı farklılık bulunduğunu belirterek çalışma sonucumuzdan farklı bir sonuç elde etmiştir. Güngör (2009), çalışmasında kız öğrencilerin erkek öğrencilere göre daha çok kitap okuduğunu belirterek çalışma sonucumuzdan farklı bir sonuca ulaşmıştır.

Araştırmanın ikinci alt problemi olan ortaokul öğrencilerinin okuma motivasyonlarının sınıf düzeyine göre değişkenlik gösterip göstermedikleri ile ilgili yapılan analiz neticesinde öğrencilerin sınıf düzeyine göre Türkçe dersi akademik başarıları ile okuma motivasyonları arasında istatistiki olarak anlamlı bir şekilde farklılaşma tespit edilmiştir.

Alan yazın incelendiğinde benzer sonuçlara ulaşılmıştır. Suna (2006), yaptığı çalışmada öğrenci okuma ilgi düzeylerinin sınıf düzeylerine göre farklılık gösterdiğini, beşinci sınıf öğrencilerinin sekizinci sınıf öğrencilerinden daha yüksek okuma ilgisi düzeyine sahip olduğunu belirterek çalışma sonucumuza benzer sonuç elde etmiştir. Topçu (2007), ilköğretim 6, 7 ve 8 . sinıf öğrencilerinin okuma alışkanlıkları ile ilgili yaptığı araştırmada öğrencilerin sınıf seviyelerinin yükselmesiyle okul dışında kitaba ayrılan zaman yüzdelerinin düştügünü belirterek çalışma sonucumuza benzer sonuç elde etmiştir.

Araştırmanın üçüncü alt problemi olan öğrencilerin anne eğitim düzeyine göre Türkçe dersi akademik başarıları ile okuma motivasyon ölçeği puanları arasında anlamlı bir farklılık olup olmadığını tespit etmek amacıyla yapılan analiz neticesinde öğrencilerin anne eğitim düzeyine göre Türkçe dersi akademik başarıları ile okuma motivasyonlarının istatistiki olarak anlamlı bir biçimde farklılaşmadığ 1 tespit edilmiştir.

Alan yazın incelendiğinde çalışmamızı destekleyen sonuçlara ulaşılmıştır. Ürün Karahan ve Taşdan (2016), yaptıkları araştırmada öğrencilerin okuma motivasyonları üzerinde anne mesleğinin anlamlı bir etkisinin olmadığını tespit ederek çalışma sonucumuza benzer sonuç elde etmişlerdir.

Katrancı (2015), yaptığı çalışmada ise araştırmamızdan farklı bir sonuç olarak annenin eğitim seviyesinin öğrencilerin okuma motivasyonları üzerinde anlamlı şekilde etkili olduğu sonucuna ulaşmiştır.

Araştırmanın dördüncü alt problemi olan öğrencilerin baba eğitim düzeyine göre Türkçe dersi akademik başarıları ile okuma motivasyon ölçeği puanları arasında anlamlı bir farklılık olup olmadığını tespit etmek amacıyla yapılan analiz neticesinde öğrencilerin baba eğitim düzeyine göre Türkçe dersi akademik başarıları ile okuma motivasyonlarının istatistiki olarak anlamlı bir biçimde farklılaşmadığ

Alan yazın incelendiğinde çalışmamızı destekleyen sonuçlara ulaşılmıştır. Soysal (2014) çalışmasında, babanın eğitim seviyesinin okuma anlama düzeyinde anlamlı bir farklılı̆̆a etki etmediğini belirterek çalışmamıza benzer sonuca ulaşmıştır. Dilbaz (2019), da yaptı̆̆ı çalışmada çalışmamıza benzer şekilde okur öz algısının baba eğitim düzeyi açısından herhangi bir farklılık oluşturmadığı sonucuna ulaşmıştır. Duran (2018) ise çalışmamızdan farklı olarak öğrencilerin okuma alışkanlığında, anne-baba eğitim seviyesi yüksek olanların lehine anlamlı farklılık ortaya koymuştur. 
Araştırmanın beşinci alt problemi olan öğrencilerin evinde kütüphane bulundurma durumuna göre Türkçe dersi akademik başarıları ile okuma motivasyon ölçeği puanları arasında anlamlı bir farklılık olup olmadığını tespit etmek amacıyla yapılan analiz neticesinde öğrencilerin evinde kütüphane bulundurma durumuna göre Türkçe dersi akademik başarıları ile okuma motivasyonlarının istatistiki olarak anlamlı bir biçimde farklılık olduğu tespit edilmiştir. Evinde kitaplık bulunduran öğrencilerin bulundurmayan öğrencilere göre okuma motivasyonu ve ilişkili olarak başarı yönünden daha iyi durumda oldukları söylenebilir. Evinde kütüphane bulunan öğrenciler kitaba daha rahat ulaşmakta ve kitap ile geçirilebilecekleri zaman daha çok olabilmektedir. Kitap ile meşguliyetin fazla olması bireyin okuduğunu daha iyi anlaması, okuma becerilerinin ve motivasyonun gelişmesi demektir.

Alan yazın incelendiğinde çalışmamızı destekleyen sonuçların hayli fazla olduğu görülmektedir. Gür Erdoğan ve Demir (2016), yaptıkları çalışmanın araştırma sonuçlarımızı destekler nitelikte olup evde kitaplıkları bulunan öğrencilerin okumaya yönelik tutumlarının evde kitaplıkları bulunmayan öğrencilere oranla daha yüksek olduğu sonucuna ulaşmışlardır. Yılmaz (2004), yaptığı çalışmasında bir evde okumaya ilişkin duyarlılığın genel göstergelerinden birisi olarak kitaplığı göstermiştir. Kitaplık bulunmasının da bu yönüyle ailedeki okuma kültürünün doğal bir parçası olduğunu belirterek çalışma sonucumuza benzer sonuç elde etmiştir.

Araştırmanın altıncı alt problemi olan öğrencilerin okul öncesi eğitimi alma durumuna göre Türkçe dersi akademik başarıları ile okuma motivasyon ölçeği puanları arasında anlamlı bir farklılık olup olmadığını tespit etmek amacıyla yapılan analiz neticesinde öğrencilerin okul öncesi eğitimi alma durumuna göre Türkçe dersi akademik başarıları ile okuma motivasyonlarının istatistiki olarak anlamlı bir biçimde farklılık olduğu tespit edilmiştir. Okul öncesi dönemde eğitim alan öğrencilerin almayan öğrencilere göre okuma motivasyonu ve akademik başarı yönünden daha önde olduklarını göstermiştir.

Alan yazın incelendiğinde çalışmamızın sonuçlarını destekleyen pek çok araştırma olduğu görülmektedir. Taner ve Başal (2005), çalışmalarında okul öncesi eğitim alan çocukların dil gelişimlerinin okul öncesi eğitim almayan çocuklara göre daha iyi olduğunu belirterek çalışma sonucumuza benzer sonuca ulaşmışlardır. Dil gelişimi iyi olan öğrencilerin de okuma becerisi ve okuma motivasyonu bakımından iyi olacakları yorumunda bulunulabilir.

Güngör (2009) yaptığı çalışmasında akademik anlamda başarılı olan öğrencilerin okul öncesi dönemde anne ve babaları tarafından diğer ebeveynlere göre daha fazla kitap okudukları sonucuna ulaşmıştır. Bu durum da okul öncesi dönemde evde ebeveynler tarafından verilen eğitimin de olumlu sonuçlar doğurduğunu göstermektedir.

Araştırma sonucumuzdan farklı olarak Yavuz (2019), yaptığı çalışmada öğrencilerin okumaya yönelik tutumları ile okul öncesi eğitim alma veya almama durumları arasında anlamlı bir farklılı̆̆ın bulunmadığı sonucuna ulaşmıştır.

Aile bireylerinin kitap okuma alışkanlıklarının çocukların kitap okuma alışkanlıklarına etkisinin büyük olduğu ve çocuklar için aile bireylerinin birer rol model olması gerektiği (Sarıkaya, 2018) alan yazında üzerinde en çok durulun husustur.

\section{Sonuç}

Araştırma sonuçlarına bir bütün olarak bakıldığında öğrencilerin Türkçe dersi akademik başarıları ile okuma motivasyonları arasında cinsiyet, anne eğitim düzeyi, baba eğitim düzeyleri arasında anlamlı bir farklılaşma olmadığı tespit edilmiştir. Bu durum öğrencilerin bu değişkenler açısından 
birbirine yakın sonuçlar verdiğini ve bu değişkenlerin başarı ile doğrudan bir ilişki taşımadığını göstermektedir. Buna karşın öğrencilerin sınıf düzeyleri, evinde kütüphane bulundurma durumu ve okul öncesi eğitimi alma açısından anlamlı bir farklılaşma tespit edilmiştir.

Bu durum öğrencilerin eğitsel faaliyetlerinin akademik başarılarına yansıdığını ortaya koymaktadır. Aynı şekilde bu çalışma ile okul öncesi eğitimin ve bireysel kütüphanelerin önemini de ortaya koymaktadır. Nitekim Millî Eğitim Bakanlığı bilhassa okul öncesi eğitimi ile ilgili çalışmaları arttırmaya çalışmaktadır. Okul öncesi eğitimin uzun ve kısa vadeli bilişsel, duyuşsal ve psikolojik etkileri öğrencilerin okuma ve akademik başarıları üzerinde de etkili olmaktadır. Öğrencilerin evinde kütüphane bulundurması ise öğrencilerin kitap okuma faaliyetlerini arttırmakla beraber okuma becerilerini geliştirmektedir. Bu durumun bir yansıması da akademik başarı olmuştur. Nitekim okuma becerisi gelişmiş bireylerin okuduklarını anlama, analiz, sentez, değerlendirme gibi becerileri geliştiği için akademik başarıları da bununla ilişkili olarak gelişme göstermektedir.

Yapılan bu araştırma bu görüşü desteklemektedir. Öğrencilerin Türkçe dersi akademik başarısı ile okuma motivasyonları arasında sınıf düzeyine göre farklılaşma tespit edilmesi ile öğrencilerin yaşı gereği bilişsel performanslarının artmasına bağlanabilmektedir. Nitekim 11 yaşındaki bir öğrenci ile 15 yaşındaki bir öğrenciyi bilişsel olarak bir tutmak doğru sonuçlar yansıtmada yetersiz kalacaktır.

Tüm bu sonuçlar öğrencilerin Türkçe dersi akademik başarıları ile okuma motivasyonları arasında bir farklılaşma olmadı̆̆ını göstermektedir. Farklılaşma gösteren ve göstermeyen tüm değişkenler de göz önünde bulundurularak yapılan bu araştırmanın sonuçları öğrencilerin okuma motivasyonları ile akademik başarıları arasında doğrusal bir ilişki olduğunu, akademik başarı ve okuma motivasyonun birbirini etkilediğini ortaya koymaktadır.

\section{Öneriler}

Ortaokul öğrencilerinin okuma motivasyonları ile Türkçe dersi akademik başarıları arasındaki ilişkinin incelendiği bu çalışmanın sonuçlarından hareketle yapılan araştırmaya ve araştırmacılara yönelik aşağıdaki önerilerde bulunulmuştur:

\section{Araştırmaya Yönelik Öneriler}

- Bu araştırma tek bir okulda yürütülmüştür. Daha geniş ve genel veriler elde etmek için farklı okullarda çalışma yürütülerek veri toplanabilir.

- Bu araştırmada çalışma grubu olarak ortaokul öğrencileri seçilmiştir. Farklı eğitim kademelerindeki öğrencilerle de benzer çalışmalar yapılabilir.

- Bu araştırmada tarama modeli kullanılmıştır. Başka bir çalışma da deneysel model kullanılarak yapılabilir.

- Bu araştırmada öğrencilerin Türkçe dersi akademik başarıları ile okuma motivasyonları arasındaki ilişki incelenmiştir. Benzer araştırmada okuduğunu anlama becerisi ile okuma motivasyonu arasındaki ilişki incelenebilir.

\section{Araştırmacılar İçin Öneriler}

- Bu araştırma ortaokul öğrencilerine yönelik yapılmıştır. Benzer bir araştırma ilkokul, lise gibi diğer eğitim kademelerine de yönelik yapılabilir. Bu şekilde Okuduğunu Anlama Motivasyon Ölçeğinin işlevselliği daha net bir şekilde ortaya konulabilir.

- Bu araştırma Bingöl ilinde uygulanmıştır. Araştırma verilerinin genelleşebilmesi için farklı illerde uygulanmasına yönelik bir araştırma yapılabilir. 
- Bu araştırma Türkçe dersine yöneliktir. Benzer bir çalışma diğer dersler için de yapılabilir.

- Millî Eğitim Bakanlığına bu gibi araştırmalar proje olarak sunulup eğitim faaliyetlerine yönelik zenginleştirilmiş etkinlikler kazandırılabilir.

\section{KAYNAKLAR}

Altunışık, R., Coşkun, R., Bayraktaroğlu, S. \& Yıldırım, E. (2010). Sosyal bilimlerde bilimsel araştırma yöntemleri, spss uygulamalı 7 (6. Baskı ed.).Sakarya: Sakarya Yayıncılık.

Büyüköztürk, Ş., Çakmak, E. K., Akgün, Ö. E., Karadeniz, Ş. \& Demirel, F. (2017).Bilimsel araştırma yöntemleri. Ankara: Pegem Akademi.

Çetinkaya, S. Ç. (2004). Afyon merkezindeki ilköğretim 8. sınıf öğrencilerinin okuma alışkanlı̆̆ (Yayımlanmamış Yüksek Lisans Tezi). Kocatepe Üniversitesi, Eğitim Bilimleri Enstitüsü, Afyon.

Çongur, H. R. (1995). Söz Sanatı (VII) Konuşmanın temel ögeleri, Dil Dergisi, (36), 54-60.

Demirel, Ö. (2003). Eğitimde Program Geliştirme. Ankara: Pegem A Yayıncılık.

Dilbaz, G. H. (2019). Ortaokul öğrencilerinin okumaya yönelik tutumlarının ve okur özalgılarının çeşitli değişkenlere göre değgerlendirilmesi (Yüksek lisans tezi). Pamukkale Üniversitesi, Eğitim Bilimleri Enstitüsü, Denizli.

Duran, T. (2018). İlkokul öğrencilerinin yazma eğilimlerinin ve okuma alışkanlıklarının çeşitli değişkenler açısından incelenmesi (Yüksek Lisans Tezi). Erzincan Binali Yıldırım Üniversitesi, Sosyal Bilimler Enstitüsü, Erzincan.

Durmuş, G. (2014). Okuma motivasyonu ölçeğinin Türkçeye uyarlaması. Uluslararası Ĕ̆itim Bilimleri Dergisi, 1(1), 16-40.

Guthrie, J. T. \& Wigfield, A. (2000). Engagement and Motivation in Reading. In M. L. Kamil, P. B. Mosenthal, P. D. Pearson, \& R. Barr (Eds.), Handbook of reading research, (pp. 403-422). New York \& London: Routledge.

Güngör, E. (2009). İlköğretim 5. sinıf öğrencilerinin kitap okuma alışkanlı̆̆ı ile Türkçe dersi akademik başarıları arasındaki ilişkinin incelenmesi (Yüksek lisans tezi). Çukurova Üniversitesi, Sosyal Bilimler Enstitüsü, Adana.

Gür Erdoğan D. ve Demir Y., E. ( 2016 ) İlkokul 4. sınıf öğrencilerinin okumaya yönelik tutumlarının farklı değişkenler açısından incelenmesi, Sakarya Üniversitesi Ĕ̆itim Fakültesi Dergisi,(32), 8596.

Kaplan, M. (2001). Kültür ve Dil(14. Baskı). İstanbul: Dergâh Yayınları.

Katrancı, M. (2015). İlkokul dördüncü sınıf öğrencilerinin kitap okuma motivasyonlarının incelenmesi. Ana Dili Ĕ̆itimi Dergisi, 3(2), 49 - 62.

Keleş, Ö (2006). İlköğretim 4. ve 5. sınıf öğrencilerinde kitap okuma alışkanlığının incelenmesi (Yüksek Lisans Tezi). Gazi Üniversitesi, Eğitim Bilimleri Enstitüsü, Ankara.

Özbay, M. (2009). Anlama teknikleri ı - okuma eğitimi. Ankara: Öncü Yayınevi.

Sarıkaya, B. (2017). Türkçe öğretiminde görsel okuma. Anemon Muş Alparslan Üniversitesi Sosyal Bilimler Dergisi, 5(3): 779-796.

Sarıkaya, B. (2018). Basılı Kitap mı, E-Kitap mı? Türkçe Öğretmeni Adayları Ne Düşünüyor? Turkish Studies Educational Sciences Volume 13/19, Summer 2018, p. 1567-1582 DOI Number: http://dx.doi.org/10.7827/TurkishStudies.

Sarıkaya, B. (2018). Türkçe öğretmeni adaylarının kitap okuma alışkanlıklarının değerlendirilmesi. Sosyal Bilimler Dergisi, 5 (20), 278-28.

Soysal, P. İ. (2014). Ortaokul öğrencilerinin okuduğunu anlamaya etki eden faktörler (Yüksek lisans tezi). 
Uşak Üniversitesi, Sosyal Bilimler Enstitüsü, Uşak.

Suna, Ç. (2006). Illköğretim öğrencilerinin okuma ilgi ve alışkanlıklarını etkileyen etmenlerin analitik olarak incelenmesi ve değgerlendirilmesi (Yüksek Lisans Tezi). Anadolu Üniversitesi, Eğitim Bilimleri Enstitüsü, Eskiş̧ehir.

Taner, M. ve Başal H. A. (2005). Farklı sosyoekonomik düzeylerde okulöncesi eğitimi alan ve almayan ilköğretim birinci sınıf öğrencilerinin dil gelişimlerinin cinsiyete göre karşılaştırılması. Ĕ̆itim Fakültesi Dergisi,18 (2), 395 - 420.

Topçu, Y. E. (2007). İlköğretim 6., 7. ve 8. sınıf öğrencilerinin okuma alışkanlıkları. Milli Eğitim Dergisi, 176, 36- 57.

Ürün Karahan, B. (2016). 5. ve 6. sınıf öğrencilerinin okumaya karşı tutum ve motivasyonlarının okuduğunu anlama becerileri ile ilişkisi. Uluslararası Türkçe Edebiyat Kültür Eğitim (TEKE) Dergisi, 5 (2), 949-969.

Yalçın, A. (2002). Türkçe öğretim yöntemleri yeni yaklaşımlar. Ankara: Akçă̆ Yayınları.

Yavuz, S. (2019). İlkokul 4. sinı öğrencilerinin okuma motivasyonlar ile okumaya yönelik tutumlarmın incelenmesi (esenler ilçe örneği) (Yayınlanmamış yüksek lisans tezi). Giresun Üniversitesi ,Sosyal Bilimler Enstitüsü, Giresun.

Yılmaz B. (2004). Öğrencilerin okuma ve kütüphane kullanma alışkanlıklarında ebeveynlerin duyarlılığı, Bilgi Dünyası, 5(2), 115-136 